\title{
Utilization of waste forest biomass: pelletization studies of torrefied sawmill wood chips
}

\author{
Michat Rejdak ${ }^{1, *}$, Agata Czardybon $^{1}$, Karina Ignasiak ${ }^{1}$, and Jolanta Robak ${ }^{1}$ \\ ${ }^{1}$ Institute for Chemical Processing of Coal, ul. Zamkowa 1, 41-803 Zabrze, Poland
}

\begin{abstract}
The paper presents the effects pelletization process of torrefied waste forest biomass - sawmill wastes. The sawmill waste are generated in significant quantities and has significant energy potential. The use of torrefaction and pelletization process enables to produce mechanically durable fuel pellets. Aim of the studies was to evaluate the effect of different kind of additives (binders) to torrefied waste forest biomass on pelletization process characteristic (production capacity, energy consumption) and properties of produced pellets (i.e. density, mechanical durability). The most effective binder among the tested was modified wheat starch. Pellets made with this addition were characterized by the highest mechanical strength.
\end{abstract}

\section{Introduction}

The development of biomass conversion processes have been an important issue for the past several decades and seems to be attractive in the future due to its clean, renewable, and carbon-neutral properties. The most important sources of biomass acquisition in Poland are currently: forestry, agriculture, industry and municipal management [1, 2]. Among biomass with potential for energy use, a significant amount of it is generated by the wood industry (c.a. 4.06 million $\mathrm{m}^{3}$ ) [3]. It is estimated that about $70 \%$ is sawmill waste (c.a. 2.83 million $\mathrm{m}^{3}$ ). However, above mentioned waste biomass is characterized some drawbacks in terms of its utilization. Its heterogeneity, low energy density and high moisture content have become major problems in its efficient transport, handling, storage and conversion into energy products.

To overcome the above drawbacks and improve quality of biomass, the thermal pretreatment e.g. pyrolysis might be used [4]. Due to the temperatures used, pyrolisis processes can be divided into: low temperature $\left(<350^{\circ} \mathrm{C}\right)$, medium temperature $\left(350-800^{\circ} \mathrm{C}\right)$, and high temperature pyrolysis $\left(>800^{\circ} \mathrm{C}\right)$ [5]. Medium- and high temperature pyrolysis is commonly used to biochar production, which is currently tested in the processes of enriching degraded soils, water cleaning, in construction, in electronics industry, in metallurgy, in medicine, and in cosmetics [6]. Low temperature pyrolysis, also known as torrefaction, is often used to thermal valorization of biomass. It is carried out in

*Corresponding author: mrejdak@ichpw.pl 
temperatures between $200-350^{\circ} \mathrm{C}$ ussually in an inert atmosphere [7-11], sometimes in hot compressed subcritical water (hydrothermal carbonization, HTC) [12-14] or saturated steam presence (steam explosion treatment) [15-17].

As result of aforementioned processes, the chemical structure of biomass undergoes certain transformations, which in turn contribute to the change in the physical and chemical properties of the obtained product. In comparison to raw biomass, the produced fuel is characterized by lower volatile matter content, increased calorific value (higher energy density), improved grindability (reduced costs of grinding) and hydrophobic properties (less risk of environmental degradation - bacterial and mycological), which makes that thermally treated biomass have more favorable usable properties in term of such processes as combustion, co-combustion and gasification applications [18-27]. Despite a number of these advantages, low bulk density of the pyrolysis products, their porous structure and excessive fragility may cause logistical problems (high transport costs, large storage areas), as well as excessive dust emissions, resulting in an increased explosion hazard [21]. However, these problems can be eliminated by the pressure agglomeration, the most commonly used method for compaction of powdery materials including biomass [21, 26-31].

Recently, the issue of densification of thermally treated biomass has been the subject of research by many authors [11, 20, 21, 26, 27, 32-39].

In general, most of them found that strength of pellets produced from thermally treated biomass decreases with increasing final temperature of biomass treatment. In most cases, pellets made from biomass processed at a temperature above $300^{\circ} \mathrm{C}$ were characterized by negligible mechanical strength. Therefore, to produce mechanically durable pellets from biomass processed at temperatures higher than $300^{\circ} \mathrm{C}$ it is necessary to use binding agents.

At the Institute for Chemical Processing of Coal (IChPW) in Zabrze for several last years, research on development of autothermal biomass carbonization technology, production of pelleted fuels from torrefied biomass, combustion test, as well as environmental aspects of biomass torrefaction technology have been performed [18, 21, 24-26, 40].

Aim of our recent studies was to evaluate the effect of different kind binders to torrefied waste forest biomass on pelletization process characteristic (production capacity, energy consumption) and properties of produced pellets (i.e. density, mechanical durability).

\section{Experimental}

\subsection{Biomass torrefaction}

Sawmill waste wood chips (mixtures of pine, spruce and alder) were torrefied in an Chemical Processing of Coal demonstration installation (capacity of up to $120 \mathrm{~kg} / \mathrm{h}$ ) under autothermal conditions at $350^{\circ} \mathrm{C}$ [21]. Properties of raw and torrefied biomass were presented in Table 1. Volatile matter content (V) was determined according to PN-EN ISO 18123:2016-01. Ash content (A) was determined according to PN-EN ISO 18122:2016-01. Ultimate analysis (C, H, N) was determined according to PN-EN ISO 16948:2015. Total sulfur content $(\mathrm{S})$ was determined according to PN-EN ISO 16994:2016. Heating value $\left(\mathrm{Q}_{\mathrm{i}}\right)$ was determined according to PN-EN ISO 18125:2017-07.

As a result of torrefaction process, the material with higher carbon content and calorific value, reduced content of volatile components, and an increased grindability (assessed by modified Hardgrove method - $\mathrm{HGI}_{\text {eqv }}$ ) in comparison with raw wood chips was obtained. 
Table 1. Properties of raw and torrefied waste chips (dry basis).

\begin{tabular}{|c|c|c|c|c|c|c|c|c|c|}
\hline Parameter & \multicolumn{4}{|c|}{ Proximate Analysis } & \multicolumn{4}{c|}{ Ultimate Analysis } & \multirow{2}{*}{ Fuel } \\
\hline $\mathrm{FC}^{\mathrm{d}} \%$ & $\mathrm{~V}^{\mathrm{d}} \%$ & $\mathrm{~A}^{\mathrm{d}} \%$ & $\begin{array}{c}\mathrm{Q}_{\mathrm{i}}^{\mathrm{d}} \\
\mathrm{MJ} / \mathrm{kg}\end{array}$ & $\mathrm{C}^{\mathrm{d} \%}$ & $\mathrm{H}^{\mathrm{d}} \%$ & $\mathrm{~N}^{\mathrm{d}} \%$ & $\mathrm{~S}^{\mathrm{d}} \%$ & \\
\hline Wood chips & 14.20 & 85.15 & 0.65 & 19.57 & 52.17 & 5.73 & 0.14 & 0.02 & 16 \\
\hline $\begin{array}{c}\text { Torrefied } \\
\text { wood chips }\end{array}$ & 33.20 & 64.83 & 0.97 & 22.65 & 62.30 & 5.02 & 0.24 & 0.02 & 68 \\
\hline
\end{tabular}

\subsection{Pelletization tests of torrefied wood chips}

The compacting tests were carried out using a pellet mill with a flat die with a nominal capacity of $150 \mathrm{~kg} / \mathrm{h}$ and a power of $3 \mathrm{~kW}$ (Fig. 1). The pellet mill was equipped with 24 and $30 \mathrm{~mm}$ die with a diameter hole of $6 \mathrm{~mm}$. Before the compacting process, the torrefied biomass was ground in a hammer mill for grains below $3 \mathrm{~mm}$. Then, the different binders in the amount of $5 \%$ by mass were added to the raw material and the mixture was humidified to the appropriate level. The following types of binder were tested: modified wheat starch, waste glycerol, molasses, sodium lignosulphonate and two binders being a mixture of the mentioned above: binder 1 (modified wheat starch $60 \%$, molasses $15 \%$, glycerol $15 \%$, sodium lignosulfonate $10 \%$ ), and binder 2 (wheat starch $60 \%$, molasses $30 \%$, sodium lignosulfonate $10 \%$ ). After homogenizing in a planetary mixer the mixture was pelletized. After densification process was completed, pellets produced were dried to moisture content below 5\%. Pellet density (apparent), mechanical strength according to PN-EN 15210-1:2010 and its bulk density were determined. The production capacity (yield) and energy consumption in the pelleting process was also assessed. Prior to the actual pelleting tests, preliminary tests were carried out to select the right amount of moisture in the feed to the process. The general view of the pellets produced is illustrated on Fig. 2.

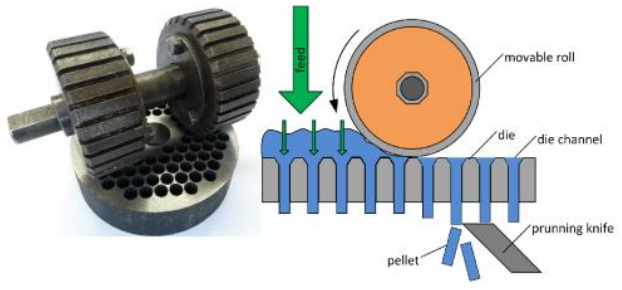

Fig. 1. The principle of flat die pellet mill operation.

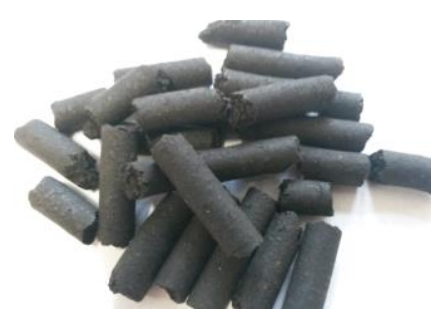

Fig. 2. General view of pellets produced from torrefied waste forest biomass.

\section{Results and Discussion}

\subsection{Preliminary tests}

Preliminary tests of torrefied biomass pelletizing were carried out for 5\% wheat starch addition. The aim was to evaluate proper level of moisture content for further tests. As can be seen from the data presented in Fig. 4 and Fig. 5 an increase in moisture content in the 
material directed to the process results in an increase in the production capacity of the pelletizer, and thus a decrease in the unit energy consumption, with a decrease in mechanical strength and density of the pellets produced. Pellet density for $30 \%, 35 \%$, and $40 \%$ moisture content was respectively: $740,720,680 \mathrm{~kg} / \mathrm{m}^{3}$.

The value of moisture content at the level of $30 \%$ is the limit value at which a very high level of energy consumption was observed. At the moisture content of $25 \%$, the die of the pellet mill was blocked. For further tests, the moisture content in the sample directed to the compacting process was set at $35 \%$.

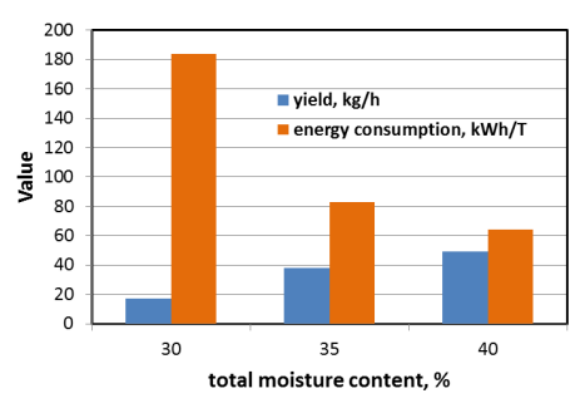

Fig. 4. The effect of moisture content on the efficiency and energy consumption during pellet production ( $24 \mathrm{~mm} \mathrm{die})$.

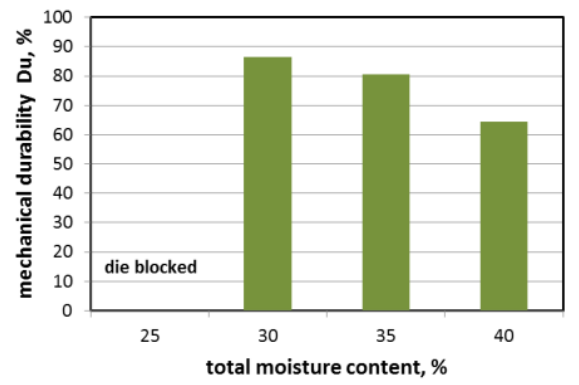

Fig. 5. The effect of moisture on pellets mechanical strength (24 $\mathrm{mm}$ die).

\subsection{Pellet production capacity}

As is apparent from the data presented in Fig. 6 the type of binder used affects the pellet production efficiency. It is caused by the influence of the binder addition on the frictional resistance of the material passing through the die holes.

For $24 \mathrm{~mm}$ die, the lowest efficiency $(30 \mathrm{~kg} / \mathrm{h})$ for waste glycerol was obtained. Slightly higher efficiency was obtained for the addition of sodium lignosulphonate and binder 2 , which amounted 34 and $35 \mathrm{~kg} / \mathrm{h}$, respectively. The highest value was obtained with the addition of molasses - the pellet production efficiency was reached $40 \mathrm{~kg} / \mathrm{h}$. Slightly lower yields were noted for wheat starch and binder 1 addition.

Different results were obtained for pelleting tests using a $30 \mathrm{~mm}$ thick die (Fig. 6-9). In general, thicker die - longer die channels - generates higher resistance during material transfer through channels, which in turn causes a decrease in efficiency (yield), and an increase in energy consumption. On the other hand, it positively affects the mechanical durability and density of pellets.

In case of production capacity (yield), the best results for addition of binder 2 were obtained $(31 \mathrm{~kg} / \mathrm{h})$. Slightly lower efficiency values: about $25 \mathrm{~kg} / \mathrm{h}$ were obtained using wheat starch and binder 1 . With the addition of sodium lignosulphonate, yield of $22 \mathrm{~kg} / \mathrm{h}$ was obtained. The lowest yield was obtained $(12 \mathrm{~kg} / \mathrm{h})$ which was surprising, due to the beneficial results obtained for the $24 \mathrm{~mm}$ matrix. In case of waste glycerol addition, the die of pellet mill was blocked after about 20 seconds from the start of work. 


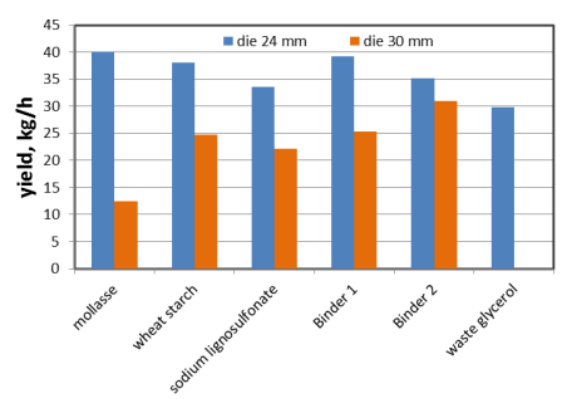

Fig. 6. The influence of the type of binder on the pellet production efficiency.

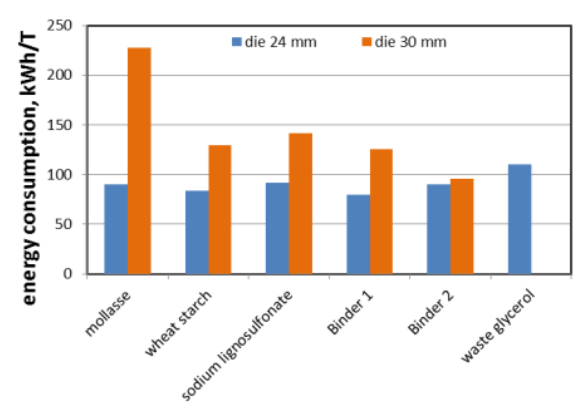

Fig. 7. The influence of the type of binder on energy consumption during pellet production.

\subsection{Energy consumption}

The energy consumption during the pelleting process of torrefied biomass due to the resistance of the material moving through the die holes is closely dependent on the binder used to pellet production. The influence of the type of binder used in pellet production on energy for two different dies: $24 \mathrm{~mm}$ and $30 \mathrm{~mm}$ is presented in Fig. 7.

In the case of $24 \mathrm{~mm}$ die, the highest energy consumption in pellet process production was noted for the waste glycerol addition, which was $110 \mathrm{kWh} / \mathrm{T}$, and the lowest for binder $1-79 \mathrm{kWh} / \mathrm{T}$. A similar result $(83 \mathrm{kWh} / \mathrm{T})$ was observed for pelleting process with wheat starch addition. Slightly higher energy consumption was achieved for: binder 2, molasses and lignosulphonate, which amounted to $90,90,92 \mathrm{kWh} / \mathrm{T}$, respectively.

If a thicker $30 \mathrm{~mm}$ die was used, a significant increase in energy consumption was observed. The highest energy consumption level was recorded for pellet production with molasses addition $-227 \mathrm{kWh} / \mathrm{T}$, and the lowest for binder $2-96 \mathrm{kWh} / \mathrm{T}$. In the case of the use of starch, binder 1 and lignosulphonate, the energy consumption was 130, 125, $142 \mathrm{kWh} / \mathrm{T}$, respectively.

In general achieved results are consistent with the results obtained for production capacity evaluation. For mixtures that generated higher resistance during pelletizing process, higher energy consumption were noted and thus, lower yield were obtained.

\subsection{Pellet apparent density}

Resistance accompanying the pelleting process also affect the density of the product obtained. In the case of a die with a thickness of $24 \mathrm{~mm}$, the density of the pellets produced was in the range of $675-768 \mathrm{~kg} / \mathrm{m}^{3}$, the highest value was obtained for waste glycerol addition and the lowest for use of lignosulphonate. Densities above $700 \mathrm{~kg} / \mathrm{m}^{3}$ were noted for the addition of molasses, wheat starch and binder 2 and amount respectively: 747, 720, $707 \mathrm{~kg} / \mathrm{m}^{3}$.

The use of a $30 \mathrm{~mm}$ thick die resulted in a slight increase in the density of the pellets produced. All of the pellets produced were characterized by a density above value of $700 \mathrm{~kg} / \mathrm{m}^{3}$. The highest density was obtained for the wheat starch additive $-781 \mathrm{~kg} / \mathrm{m}^{3}$, and the lowest for molasses $-716 \mathrm{~kg} / \mathrm{m}^{3}$. The influence of the type of binder on pellets density for different dies is presented on Fig. 8. 


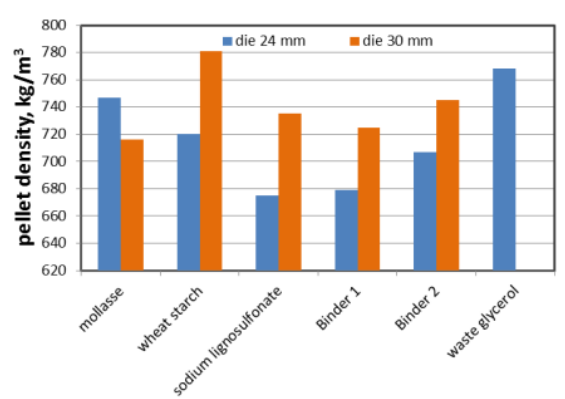

Fig. 8. The influence of the type of binder on the pellets density.

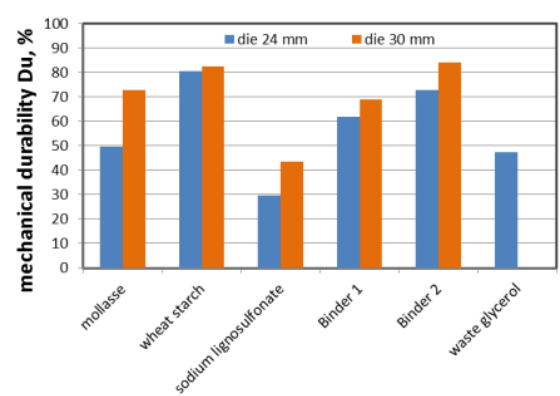

Fig. 9. The influence of the type of binder on the pellets strength.

\subsection{Mechanical durability of pellets}

Both: type of the binding additive and the die size has an impact on obtained mechanical durability of pellets produced. The influence of the type of binder on pellets mechanical strength is presented on Fig. 9.

The highest mechanical durability was obtained with the addition of wheat starch $80.5 \%$ and binder $2-72.7 \%$. The strength of pellets produced with the use of other additives was at a much lower level. For the lignosulphonate additive the strength was $29.5 \%$. Increasing the thickness of the applied die had a positive effect on the mechanical strength of the pellets produced. The highest strength was obtained for the binder $2(83.9 \%)$ and starch $(82.5 \%)$.

The type of binder and the thickness of the die affect the amount of the obtained undersize (below $3.15 \mathrm{~mm}$ ) (Fig. 10.). Too much amount of it reduces the efficiency of pellet production due to the necessity of turning the undersize back to re-pelleting.

The best results were obtained in the case of wheat starch and binder 2, for which in both cases (die thickness 24 and $30 \mathrm{~mm}$ ) the undersize below $3.15 \mathrm{~mm}$ content did not exceed $5 \%$. For the $24 \mathrm{~mm}$ die, the worst results were recorded for waste glycerol $-38.5 \%$. The use of a thicker die resulted in a significant decrease in the undersize content in case of molasses additive and a slight decrease for lignosulphonate. For the other additives (starch, binder 1 and 2) the content of the undersize has practically remained unchanged.

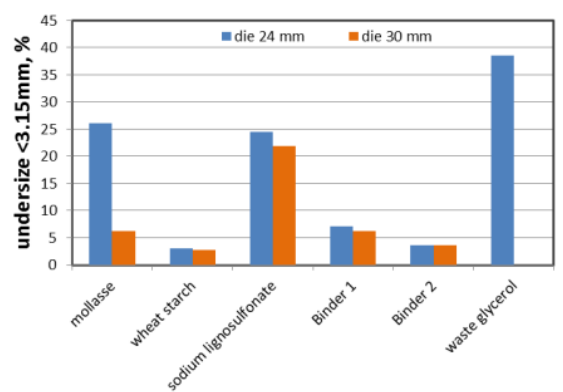

Fig. 10. The influence of the type of binder on the amount of undersize.

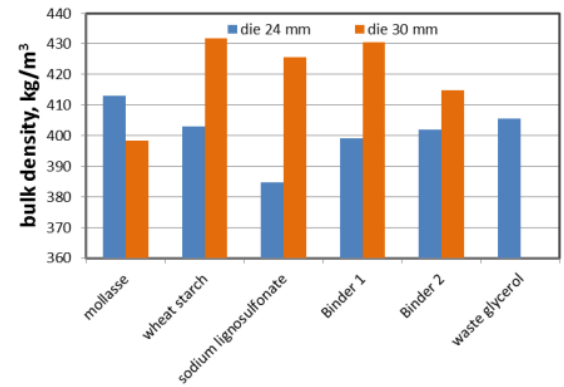

Fig. 11. The influence of the type of binder on the pellets bulk density. 


\subsection{Bulk density of pellets}

The influence of the type of binder on bulk density of pellets is presented on Fig. 11. In the case of a $24 \mathrm{~mm}$ die for all samples tested, with the exception of pellets with the addition of lignosulphonate, a bulk density of approx. $400 \mathrm{~kg} / \mathrm{m}^{3}$ was obtained. The highest density was obtained for molasses $-413 \mathrm{~kg} / \mathrm{m}^{3}$ and the lowest for lignosulphonate $-385 \mathrm{~kg} / \mathrm{m}^{3}$. The use of a thicker $30 \mathrm{~mm}$ die positively influenced the achieved bulk density, with the exception of pellets with the addition of molasses, whose lower bulk density results from a slightly lower apparent density of pellets.

\section{Conclusions}

On the basis of the conducted studies, it was found that it is possible for tested material torrefied waste forest chips to produce pellets with a mechanical strength of approx. 80\% using a pelleting machine with a flat die with a power of $3 \mathrm{~kW}$. The moisture content is the key parameter affecting the effectiveness of the pelleting process. The higher the moisture content in the material, the higher process efficiency and lower energy consumption were observed. An increase in the moisture content, however, causes a decrease in the density of the compacted material, decrease in mechanical strength and require more energy for drying of produced pellets. Lowering the moisture content below a certain limit level results in a drastic increase in resistance to material compacting and blocking of the die. For the investigated case, the optimum moisture level was $35 \%$. But it should be taken into consideration that it might depend on the origin and properties of the material, as well as the type of pelleting equipment.

The most effective binder among the tested was modified wheat starch. Pellets made with this addition were characterized by the highest mechanical strength. Another additive that gave satisfactory results was a binder 2, which consisted of: wheat starch $60 \%$, molasses $30 \%$, and sodium lignosulfonate $10 \%$. The pellets obtained with it had slightly lower mechanical strength than those made with starch. The advantage of binder 2 is approx. 18-20\% lower than the price of modified wheat starch.

Work carried out as part of the project titled „Biocoal for Power Generation” (BIOPOGEN), financed by the European Institute of Innovation and Technology (EIT).

\section{References}

1. E. Pietras, Inżynieria i Ochrona Środowiska 20, 1, 59-70 (2017)

2. S. Parzych, Leśne Prace Badawcze 76, 3, 256-264 ( 2015)

3. P. Gołos, A. Kaliszewski, Instytut Badawczy Leśnictwa, 59-76 (2013)

4. M. J. C. Stelt, H. Gerhauser, J. H. A. Kiel, K. J. Ptasinski, Biomass Bioenergy 35, 9, 3748-3762 (2011)

5. J. Xiao, F. Li, Q. Zhong, J. Huang, B. Wang, Y. Zhang, Journal of Analytical and Applied Pyrolysis 117, 64-77 (2016)

6. H. P. Schmidt, Ithaka Journal 1, 286-289 (2012)

7. J. Peng, W. H. Chen, X. T. Bi, Renewable and Sustainable Energy Reviews 44, $847-866(2015)$ 
8. M. J. Prins, PhD Thesis, Technische Universiteit Eindhoven, The Netherlands (2005)

9. J. H. A. Kiel, BUS final meeting (Wageningen, The Netherlands, 2007)

10. T. G. Bridgeman, J. M. Jones, I. Shield., S. P. T. William, Fuel 87, 6, 844-856 (2008)

11. M. J. Prins, K. J. Ptasinski, J. J. Janssen, Journal of Analytical and Applied Pyrolysis 77, 1, 28-34 (2006)

12. M. T. Reza, M. Uddin, J. G. Lynam, C. J. Coronella, Biomass and Bioenergy 63, 229-238 (2014)

13. S. K. Hoekman, A. Broch, C. Robbins, Energy Fuel 25, 1802-1810 (2011)

14. H. S. Kambo, A. Dutta, Applied Energy 135, 182-191 (2014)

15. P. S. Lam, S. Sokhansanj, X. T. Bi, C. J. Lim, S. H. Larsson, Bioresource Technology 116, 396-402 (2012)

16. P. S. Lam, P. Y. Lam, S Sokhansanj, X. T. Bi, C. J. Lim, Biomass Bioenergy 56, 116-126 (2013)

17. Z. Tooyserkani, S. Sokhansanj, X. Bi, C. J. Lim, J. Saddler, A. Lau, Transactions of the ASABE 55, 6, 1-8 (2012)

18. M. Kopczyński, J. Zuwała, Energy Policy Journal 16, 4, 271-284 (2013)

19. M. J. Prins, K. J. Ptasinski, F. J. Janssen, Energy 31, 3458-3470 (2006)

20. W. Stelte, A. R. Sanadi, L. Shang, J. K. Holm, J. Ahrenfeldt, U. B. Henriksen, BioResources 7, 3, 4451-4490 (2012)

21. A. Czardybon, K. Ignasiak, M. Rejdak, A. Sobolewski, Przemysł Chemiczny 96, 11, 2265-2271 (2017)

22. P. C. A. Bergman, Combined torrefaction and pelletisation: the TOP process (ECN publication, 2005)

23. H. Pawlak-Kruczek, M. Czerep, Nowa Energia 1, 31-38 (2016)

24. M. Kopczyński, J. Zuwała, Chemik 6, 540, 540-545 (2013)

25. J. Lasek, M. Kopczyński, M. Janusz, A. Iluk, J. Zuwała, Energy 119, 362 (2017)

26. M. Rejdak, A. Czardybon, K. Ignasiak, A. Sobolewski, J. Robak, Journal of Ecological Engineering 18, 1, 183-192 (2017)

27. W. Stelte, C. Clemons, J. K. Holm, A. R. Sanadi, J. Ahrenfeld, L. Shang, U. B. Henriksen, Biomass and Bioenergy 35, 4690-4698 (2011)

28. A. Bazagran, S. L Rough, G. Mckay, Biomass and Bioenergy 70, 489-497 (2014)

29. M. Rejdak, R. Winkler, K. Supernok, K. Ignasiak, Inżynieria Ekologiczna 49, 100-106 (2016)

30. S. Obidziński, M. Joka, O. Fijoł, International Agrophysics 31, 515-523 (2017)

31. G. Borowski, Environment Protection Engineering 33, 2, 79-86 (2007)

32. M. Phanphanich, MSc Thesis, University of Georgia, USA (2010)

33. J. H. Peng, X. T Bi, S. Sokhansanj, C. J. Lim, Energy Fuels 26, 3826-3939 (2012)

34. J. Peng, H. Bi, C. Lim, S. Sokhansanj, Energy Fuels 27, 967-974 (2013)

35. H. Li, X. Liu, R. Legros, T. Xiaotao, C. Bi, C. J. Lim, S. Sokhansanj, Applied Energy 93, 680-685 (2012) 
36. W. Stelte, N. P. K Nielsen, H. O. Hansen, J. Dahl, L. Shang, A. R. Sanadi, Biomass and Bioenergy 53, 105-112 (2013)

37. H. Li, X. Liu, R. Legros, T. Xiaotao, C. Bi, C. J. Lim, S. Sokhansanj, Applied Energy 93, 680-685 (2012)

38. L. Shang, N. P. Nielsen, J. Dahl, W. Stelte, J. Ahrenfeldt, J. K. Holm, T Thomsen, U. B. Henriksen, Fuel Processing Technology 101, 23-28 (2012)

39. P. Nanou, W. Huijgen, M. Carbo, J. Kiel, Biomass and Bioenergy 111, 248-262 (2018)

40. M. Bałazińska, Polish Journal of Environmental Studies 26, 6, 2471-2477 (2017) 